\title{
The hedonic delights of frugality: Pound store shopping in austere times
}

\author{
Alison Hulme \\ University of Northampton, UK
}

\section{Abstract}

This article explores the attitudes of pound store shoppers in the United Kingdom and the ways in which 'consumptive thrift' (spending to save) has become embedded in popular culture. Through an analysis of ethnography carried out in low-income urban areas with regular pound store shoppers, it argues that a culture of bargain seeking exists, which is unique to the current era. While in previous eras hedonic pleasures were acknowledged, including those of spontaneity and disposability, they were not dialectically linked to economic motivations in the same way as they now are. Factors such as frugality and 'saving' have made bargain stores a crucial feature in an economic climate that requires consumer spending but preaches individual economic responsibility. The bargain seeker's hedonic pleasures are therefore utilized by the State as part of strategic economic pathways through straightened times.

\section{Keywords}

Frugality, austerity, hedonic, pound stores, bargains, thrift

\section{Introduction}

In 'Thrift shopping: Combining utilitarian thrift and hedonic treat benefits', Fleura Bardhi and Eric Arnould (2005: 223) propose a dialectical perspective of shopping that challenges Daniel Miller's positioning of thrift and treat in opposition to one another (see also Miller, 1998). In contrast, they argue the role of thrift can coexist with that of treat and that the related shopping practices are at once economic and hedonic (Bardhi and Arnould, 2005: 223). This article draws upon their argument and extends it to explore the ways in which UK pound store shoppers are not only engaged in shopping that is both economic and hedonic, but in doing so are performing a type of shopping that enables positivity towards frugality and can aid public acceptance of the austerity rhetoric espoused by right-wing politicians and carried out through government policies since 2009.

Miller (2013) builds his argument in A Theory of Shopping. Using evidence from ethnographic research in north London, he asserts that while shopping trips often begin by being about the pleasure of spending money, they frequently shift to focusing on saving money and play upon traditional notions of restraint and 
sobriety being somehow more respectable than immediate gratification (Miller, 1998). Miller describes everyday shopping as containing two values - that of being thrifty ('saving' money) and that of expressing devotional love to significant others (spending). In doing so, he adopts a dichotomous perspective of shopping as either provisioning or hedonic. Provisioning shopping is 'everyday', conducted out of necessity, and according to a utilitarian normative model in which individual desires are suppressed (Miller, 1998), whereas with hedonic shopping, goals are concerned with the satisfaction of particular individual desires, and the shopper regards it as an extravagance that lies outside the constraints of necessity.

For Miller (1998) then, hedonic shopping is about self-indulgence and 'treat', while provisional shopping is concerned with thrift and short-term sacrifice in order to reach more substantial long-term goals, making it a more 'moral' act. ${ }^{1}$ Key to Miller's overall argument is the idea that thrift defers the 'treat' to a future moment and that this deferral is pleasurable for the shopper as part of sacrifice, in similar ways to which sacrifice is conceived of by anthropologists. In other words, essentially, this sacrifice is about love (in the widest sense). Miller (1998) argues its purpose 'is not so much to buy the things people want, but to strive to be in a relationship with subjects that want these things' (p. 148). This thrift is aligned to Lastovicka et al.'s (1999) 'frugal consumer' who understands being thrifty in terms of the sacrifice of present consumption for savings and a better future.

In contrast to Miller, Bardhi and Arnould (2005: 233) argue that shopping dialectically engages with provisioning, thrifty, economic practices, at the same time as hedonistic, treat-seeking practices. They argue that the role of thrift can coexist with that of treat and that the related shopping practices are at once economic and hedonic, enabling consumers to negotiate and realize a diversity of moral and experiential experiences (Bardhi and Arnould, 2005: 223). (This argument is also asserted by Falk and Campbell, 1997, and Sherry, 1990.) Bardhi and Arnould's (2005) thrift shoppers 'understood and practiced thrift in coexistence with spending (shopping)' (p. 228) and can be contrasted to Lastovicka et al.'s (1999) 'frugal consumer' who understands being thrifty in terms of the sacrifice of present consumption for savings and a better future. Bardhi and Arnould (2005: 228) argue that thrift is not entirely about deferred gratification, as Miller suggests, because the hedonic pleasure to be gained in thrift shopping is often about the pleasure of a treat in the present through a thrifty purchase.

This enables a conception of thrift shopping in which the individual can escape being posited as a kind of never-ending calculating machine, who walks around weighing up present sacrifice against future satisfaction as they shop. This individual is the one that most mainstream economic history is only too familiar with, Smith's 'economic man' who through careful consideration of spending and saving embodies consumerism and thrift and fuses them together in a symbiotic relationship. In contrast, Bardhi and Arnould's shopper has rather more agency to 
portray themselves as operating based on alternative logics of consumption. This is not to say, however, that such alternative logics do not get usurped by other logics at play, as this article will show.

In agreement with Bardhi and Arnould then, this article argues that thrift shopping need not therefore be only economic, and that while for many who shop in pound stores economic necessity is the key factor, hedonic pleasures should also be acknowledged. ${ }^{2}$ These hedonic pleasures are discussed in light of various factors that typify pound stores, namely functionality, and the ways in which the simplicity of the single price encourages a specific type of spontaneity. The article then goes on to discuss these findings and how the dialectical nature of shopping in bargain stores feeds into attitudes and behaviours that tend to support government austerity policies and rhetoric of 2009 onwards, even when shoppers do not intend this to be the case. In the author's earlier work, this state-backed call for consumers to spend carefully was termed 'consumptive thrift', and this term will be used throughout this article to help analyse the ways in which bargain store shopping contains both economic and hedonic elements.

Key to this analysis is the idea that consumers must continue to spend in ways that feed into the mainstream economy, rather than engaging in practices that circumvent capitalism (such as freecycle or un-taxed car boot sales), but that this spending must be careful - curtailed, frugal and therefore 'responsible'. This article takes the consumptive thrift of pound store shoppers and unpacks it, in order to reveal how it both challenges assumptions about such shopping in terms of the individual's pleasures and perpetuates state rhetoric on economic morality and economically desirable behaviour of those on low incomes.

\section{Methodology}

The methodological approach of this study was ethnographic, with the author engaging in participant observation by accompanying regular pound store shoppers over the course of 1 year (2010-2011) in various stores in south-east London. The ethnography aimed to understand what motivated consumers to shop in pound stores and how they perceived such shopping in the context of their everyday lives. Specifically, this aim was in order to be able to explore claims that pound store shopping was either functional or hedonic.

This ethnographic work followed on from the author's previous work with pound store consumers. ${ }^{3}$ The author observed shoppers while accompanying them around stores as they shopped and informally asking them about their choices, thus gaining both observational and verbal data. The stores visited were those most frequently visited by participants in the study. The accompanied shops usually lasted approximately 2 hours and were unstructured; participants were simply asked to talk the author through where they were going and why and what 
their motivations and thoughts were as they shopped. These trips were recorded using wearable recording devices, and field notes were taken at the time. These data were then analysed and coded using standard content analysis techniques in order to ascertain key emergent themes.

The author sourced participants initially by being present in pound stores and talking to other shoppers. This strategy enabled five key participants to be identified. A subsequent three participants were identified via these key participants, and a subsequent four by the author introducing the project to more shoppers on her own shopping trips. So, overall, the study included 12 regular pound store shoppers, 9 of whom were female. All were aged between 18 and 55; two had higher education; all but one (the 18-year-old) were working; 10 of the 12 had children and 5 of those 10 had children still living with them at home. All participants described themselves as regular pound store shoppers and shopped in pound stores at least once a week. While the first five participants had been regular pound store shoppers for at least 5 years (some for much longer), the subsequent shoppers had only begun shopping in such stores in the last 1-5 years. The author shopped with the first five key participants (separately) fortnightly over the course of 3 months. She then shopped with the subsequent seven participants at least once a month over the course of the rest of the year. This second group of shoppers was asked specifically whether economic conditions in the past 5 years had been the cause of them beginning to shop in pound stores.

The emergent themes form the structure of this article, as they enable a definition of the specific ways in which the dialectic relationship between the economic and the hedonistic plays out in pound store shopping through key 'pleasures'. These are (1) the pleasure of the aesthetic functionality of the store, and (2) the pleasure of the simplicity of the single price attached to most, if not all, goods in such stores. The analysis that follows these findings will explore each of these pleasures in the context of austerity in the United Kingdom.

\section{The pleasure of the functional}

British high streets have seen a huge increase in the number of pound stores over the past 6 years. Large pound store chains are now appearing in middle-class areas as well as in those that are less economically prosperous. ${ }^{4}$ The design of such stores is functional in the extreme in terms of the organization and display of products, with items simply placed on uniform shelves according to their product category. Participants in this study spontaneously mentioned the functionality of the pound stores they shopped in, often talking about that aspect of them quite animatedly and expressing the pleasure they gained from shopping in a store that 'does what it says on the tin', or 'is honest about its products', or 'has no pretence'. 
These characteristics were all spoken about as being indicated by the way in which sections of aisles were clearly labelled 'home' or 'cosmetics' or 'toys', and so on, but also by the way in which products were simply arranged on shelves in their correct sections rather than being grouped together to create themes or displays. Participants recognized that such displays operated to entice consumers to purchase products from a range of categories, when their initial intention had been simply to buy one specific product. Paul explained how in non-pound stores a football might be displayed alongside football kit (boots, shorts, etc.), whereas in the pound store it was just in a large container with many other balls in the toy section. So, it seems that with the increase of this functional aesthetics on the average high street comes a sense of enjoyment of the un-glamorous and unchanging on the part of the consumer. Stores that disregard methods of display acquire a kind of counter-prestige from the very fact of being seen not to participate in the logic of display. In part, this is connected to a sense on the part of the consumer that there is less trickery involved - that the store is being honest; 'upfront' was the word many participants used.

Many participants also explained how they felt the functional aesthetics of the pound store alleviated the necessity to consider how one might move throughout the store. For example, Georgie talked of how 'the store just leads you round and you just stop when you get to the section you need'. Helen explained how she almost felt a sense of relief to be able to 'relinquish responsibility' and simply follow the aisles rather than wandering through various unlabelled displays organized in clusters as opposed to straight lines, as one would in a department store. She felt there was a distinct, and welcome, lack of decision-making required of the consumer because 'you have to do as the shop's layout tells you' and can 'put her head on hold'. Alan spoke of how the arrangement of the stores meant he did not pause or go 'off task' and could enjoy the knowledge that he was being 'efficient' with his time when shopping in pound stores. Sue appreciated how ordering products in this straight-forward manner meant she did not have to 'work out' the layout of the store and found it a 'refreshing break' from the supermarkets which she perceived as 'constantly changing where they put things so you can never get used to it and are always having to waste time and mental energy re-learning where things are'. It was common, then, for participants to gain pleasure in various ways from the functionality of the pound store, based on a sense of it being honest about itself and a sense that one was preserving mental energy of 'headspace' in not having to think about where to wander. In fact, wandering was effectively impossible in the pound store, and this was a source of relief and pleasure for participants.

In an attempt to further understand this attitude towards functional layout and the 'headspace' it provided, participants were asked how they would feel wandering around a beautiful seasonal display in a big department store, for example, Christmas at Selfridges. Most responded that they might enjoy it but 
would see it as a totally different activity more akin to going to see a show. For most though, this did not necessarily mean it would be a more enjoyable activity. Paul, for example, commented, 'if I wanted to see a show, I would go and see a show, not go shopping'. Sue felt there was limited pleasure to be gained from wandering around shops she did not feel she would buy anything in due to the cost (and her own desire not to spend large amounts of money). Georgie felt the 'thrill' of purchasing 'small things' was equal to, if not better than, that of large purchases that one might regret or feel guilty about. Even those participants who felt glamorous department stores were pleasurable spoke of 'not wanting that environment all the time' - Chantelle saying how it could be 'tiring' to be exposed to those kinds of stores constantly. Overall, there was a sense that one could become somehow saturated in glamorous displays and that the pound store provided a welcome contrast. This was true for those participants who shopped in pound stores due to necessity, as well as those who had a greater element of economic 'choice' in where they shopped.

It is interesting that this mimics a debate between two of the oldest rivals in marketing history, the French entrepreneur Édouard Leclerc (1926-2012) and the American-Colombian Bernard Trujillo (1920-1971). Leclerc bought goods directly from manufacturers and placed them directly on shelves in unpacked boxes with little regard for 'display' of any kind, based on a conviction that this was the most honest way of treating the customer. He believed in delivering the lowest price for the consumer throughout and was prepared to make less profit on each unit than anyone else. Leclerc's model proved successful and he became a household name in France, despite earning himself the rather mocking title of 'L'epicier' (The Grocer). However, he faced an ongoing battle with the increasing prevalence of 'modern marketing methods' as devised and advocated by Bernard Trujillo. Trujillo believed in using lights and display to create a spectacle of 'permanent circus' that was almost magical in its ability to create a trance-like state in consumers (see Bowlby, 2000: 166). This circus would enable the creation of 'islands of losses' (loss leaders) amid 'oceans of profit' - a trickery that ran very much against the grain of Leclerc's honesty towards the customer. While history on the whole has seen modern marketing methods dominate retail practices across the globe, Leclerc's philosophy continues to triumph in pound stores and low-end stores more generally, and participants certainly echoed Leclerc's conviction that functionally piled goods suggested honesty to the customer.

However, this 'stocky' display typically witnessed in pound stores cannot simply be analysed as an enjoyment of the disregard for display on the part of the consumer. It is also a powerful signifier of the goods being abundant and inexpensive, powerfully suggesting that since there are many products, they are bargains to be 'snapped up' as they will sell quickly (else there would not be so many available). The functional, stocky display then suggests a certain urgency - a need on the part of the consumer to make quick decisions and act upon them. Participants showed 
their recognition of this by explaining how they noticed there were often some product lines in pound stores that appeared seemingly randomly and never reappeared. The presence of such product lines created a sense that to be a good bargain hunter one had to act quickly now and again. As Kim said,

I like that it's predictable and you know what you can expect to find in the pound shop when it comes to basic household products and that... but on the other hand now and again there'll be something a bit random and it's quite fun.

Stocky display then was part of the pleasure participants experienced in their own sense of being market mavens and adept at finding products they felt were bargains.

\section{The pleasure of the single price}

In addition to the pleasure to be gained from the functional aesthetics of the pound store, many participants also enjoyed a kind of simplicity attached to the fact that the pound store operates under a single price, that is, everything costs f1. Tracey, for example, described how she would sometimes take her children on a 'mini spending spree' as a specific pound store local to where they lived. She explained,

I tell them we have fifteen pounds between us all, so we can each pick five whole things and put them in the basket. It's such fun because you feel you can throw caution to the wind a little and that you are choosing little treats for yourself in a quite extravagant way, only it's not extravagant 'cos we're only spending fifteen quid. And the kids love it. They feel it's so exciting to be able to choose five different things - five!'

For Kim, the pleasure was more to do with provisioning and was about 'being able to keep track of what you've spent really easily'. Alan felt that this accounting for what was spent by counting objects in a shopping basket actually caused him to spend less and question his need for each object he put in, so the pleasure was very much about expedient provisioning as opposed to guilt-free 'spending thrill' as it was for Tracey. Georgie's comments were typical of many participants; she felt that

the fact everything is $f 1$ means I don't have to go round totting things up in my head and working out whether special offers are worth it or not... I really hate always having to work out special offers and try to see through them. 
Similarly, Paul said,

when everything is $f 1$ you can just pick something up and think, yeah that's good value for $f 1$, or it's not... you don't have to work out whether it's good because there are 6 in the pack or it's buy one get one free etc.

So, for many participants the single price was a break from what they felt to be an incessant need or responsibility on their part to make relatively complicated financial calculations in order to be a wise consumer, good bargain hunter and market maven. Rather, the pound store enabled a more immediate and intuitive sense of whether or not a product was of good value. Helen, for example, referred to herself as an 'excellent bargain hunter' and took great pride and pleasure in her ability to spot what she felt were the genuine bargains, even within a single-price store. She explained how when shopping in pound stores, she was always looking for specific items - 'things that really are cheaper than in other shops... cleaning products and bathroom stuff... but never kitchen stuff'. She explained how she believed kitchen utensils

normally break and then you have to buy another and then you've spent as much if not more than you would have done if you'd bought the corkscrew or whatever it was somewhere else... and I never buy socks or tea-towels because although they look cheap, you can actually get them much cheaper from supermarkets or other large stores.

Helen, then, was a less usual pound store consumer and may well have managed to only buy the commodities that made the pound stores the least profit, but her emotional relationship to bargain hunting only accentuates the potential thrill of mundane shopping, so proving the dialectical relationship between economic and hedonic shopping. For Helen, this thrill was about 'being successful' as a shopper or bargain hunter and a sense of not falling for the 'trickery' of the market.

For almost all participants then, pound store shopping was precisely about not having to think about being a maven. The overriding belief among participants was that by its very nature, the pound store held the best bargains, and one was a wise shopper simply by being present in such a store. Asked whether they felt products were cheaper in pound stores than in other types of store, all participants agreed to some extent, most explaining as Paul did that:

sure things aren't as good quality as they would be in other shops, but basically the same product is cheaper in a pound store, so if you think you won't notice the difference in quality much, then it's a bargain for you isn't it... 
The security of this knowledge led many to experience hedonic pleasure in a sense of what they consistently referred to as 'freedom' provided by the single price and its role as an apparent marker of the bargain status of the commodity it referred to. The use of the word 'freedom' is interesting here, as it is the sense of freedom that was crucial in enabling spontaneous purchasing practices among participants. Knowing how much one is spending simply by counting how many objects one has in one's basket provides the ability to purchase spontaneously and without concern over price. Therefore, pound store shopping, as a blend of hedonic and economic shopping, is often characterized by immediacy - a knowledge that the goods are cheap and will not last long, but that they can be replaced easily and without economic concern. This enables a re-living of the hedonic pleasures of purchasing from the pound store - pleasures that are essentially not about a product satisfying a need for any notable period of time, but about the knowledge a product is likely to wear out, but is easily replaceable. For example, Sue explained how she preferred buying dishcloths that wouldn't last long but were cheap:

I just can't bear to spend over a pound on something so dull, so basic. I know if I spend more they might last longer, but I get more pleasure from thinking that I haven't spent much on things that should just be there in life, you know, things you don't want to think about!

(Of course, the irony here is that many such products can be purchased for under $\mathrm{f1}$ in supermarkets or elsewhere.) The hedonic pleasure then is in the feeling that money has been saved to spend on things that are not just 'life's basics'. Pound store provisioning is hedonic in its promise of having not wasted money on dull necessities. The pleasure in the logic of the pound store commodity is, therefore, one step removed from traditional consumer desire in that the object itself is not expected to satisfy (at least not for long); satisfaction comes instead from the ability to possess in a carefree and (apparently) economically expedient manner.

For many participants then (even some of those who felt they had little choice but to shop in them), the pound store satiated the need to feel agency as a consumer while simultaneously enabling an apparent escape from the responsibility of this agency. They could feel they were making sensible purchasing choices (using their agency) while shopping in a place that enabled them not to have to consider each and every purchase individually (avoiding responsibility).

\section{Analysis: Pound stores and the politics of austerity}

The current era of 'austerity' began in the United Kingdom following the then Prime Minister David Cameron's keynote speech to the Conservative Party Forum in Cheltenham on 26 April 2009, in which he insisted upon the necessity of 
decreasing government spending, using the phrase 'Age of Austerity'. ${ }^{5}$ This message was backed by then Chancellor, George Osborne, in his now muchquoted 'we're all in this together' speech, in which he stated, 'These are the honest choices in the world in which we live and we have made them today. Anyone who tells you these choices can be avoided is not telling you the truth. We are all in this together'. ${ }^{6}$ In using the word austerity, Cameron and Osborne were, according to many commentators, intentionally inviting echoes of wartime and post-war austerity (see Bramall, 2013; Clarke and Newman, 2012; Ginn, 2012; Hinton and Redclift, 2009). Most recently, Owen Hatherley has argued there continues to be a wilful play upon a collective memory of wartime government campaigns, such as 'digging for victory' or 'make- do-and-mend'. ${ }^{7}$ He asserts there is a politically and ideologically charged intent to connect the wartime era with the present era, played out through retro renditions of the wartime tagline 'keep calm and carry (Hatherley, 2015).

Certainly, when Cameron used the phrase 'age of austerity', it was by way of a comparison to an immediately preceding era that he referred to as an age of 'irresponsibility'. In doing so, he therefore connected austerity to economic responsibility on the part of individual citizens, for the sake of the nation. The emphasis on 'hard-working families' throughout the 2015 UK election campaign was extreme, with the phrase being repeated seemingly ad infinitum. As David McWilliam argues (2016), this return to a concept of the

deserving poor, was used to justify the rollback of benefits and services under the austerity programme, and was predicated on 'a neoliberal ideology that views unemployment and poverty as stemming from personal failings rather than the ways in which the free market has shaped British society since the election of Margaret Thatcher in 1979. (p. 42)

This line of thinking can most obviously be associated with Charles Murray's ${ }^{8}$ (2015) neo-Victorian argument that the welfare state has created a work-shy, antisocial and dependent underclass, who need rousing from their laziness and squalor by a discipline and stability like that associated with the Victorian era. As Bauman (2004) argues, the underclass has become a term that is effectively a tool of those with greater power and serves to homogenize those who find themselves in poverty for a huge variety of reasons into one unified 'social problem'. This framing of the underclass can be witnessed in the many television formats that tapped into the austerity rhetoric, judging people on their spending habits, their household clutter, their attempts to live like celebrities or indeed their survival on benefits (see Saints and Scroungers, Benefit Street, The Only Way Is Essex, Right on the Money, Britain's Spending Secrets, Til Debt do us Part, the list goes on). The logic of such programmes has provided and retained the ideological rationale for welfare cuts which, ironically, despite an apparent adherence to One Nation 
politics have most harmed those with the least, for example, the disabled and single parents, creating a more polarized society than previously existed. (Among others, both Bev Skeggs, 2012, and Angela McRobbie, 2008, have looked at televisual representations of the working classes, particularly women, in terms of themes such as 'respectability'.)

The current 'Age of Austerity' then became a pervasive mix of nationalism, economic individualism and moralism, promoted as collective interest and a return to some kind of nostalgic 'simplicity' that never existed. As Clarke and Newman argue (2012), 'this is the collective imagery that the Coalition has tried to summon up - a nation united in the face of adversity' (p. 303), a nation whose support is garnered by the creation of a sense of the absolute necessity to avert disaster by everyone pulling together as if there were an external enemy on our shores hence the success of appealing to wartime campaigns of thrift and collective effort. Indeed, in an article for The Guardian in 2010, historian David Kynaston (2010) offered a comparative account of the two austerities.

Given this socio-political context in which financial responsibility and personal denial are emphasized, it is particularly interesting that an aesthetics of functionality and the single-price policy of pound stores have come to signify a 'freedom' that enables spontaneous spending in times of austerity. Faced with the austerity message of reducing personal debt and reigning in spending while essentially keeping calm and carrying on consuming (consumptive thrift in other words), the pound store becomes an increasingly viable option for consumers seeking cheaper alternatives and a much-missed sense of buying power. In this sense, it enables (typically) less well-off and average-earning customers to be good 'consumer citizens' ${ }^{9}$ (whether they intend to be or not). Certainly, the austerity rhetoric espoused by David Cameron and his predecessors was not something that all participants felt particularly resonated with, but in their shopping habits, many were behaving in ways austerity policies required of them, without fully realizing it.

Self-awareness of 'responsible economic behaviour', for example, was clear, especially in those participants who had started shopping in pound stores in the last few years. Georgie did not relate her financially responsible behaviour to a personal concern with austerity policies, but admitted to having been made more aware of 'living within her means'. Sue also felt she had always been responsible as an individual, but that recent political discourses she had heard in the news had made her feel that more people should be looking for ways to cut back on things they could not afford. The pound store was seen by participants as part of the potential solution to the United Kingdom's economic situation; it was recognized as enabling people to buy what they needed in affordable ways. 
were seen as 'lowering the tone of the high street' (as Kim explained) but that actually they were 'keeping the high street alive'. As a result, many participants felt they were playing a part in keeping the high street alive, and a small part in helping the economy, without even changing their habits. In fact, there was a sense among around half the participants that their own economic behaviour was a model for what everyone needed to do. For example, Tracey said, 'people feel they ought to be able to have everything they want now at the drop of a hat'. This is interesting as Tracey felt that spontaneity when it came to cheap pound store items was entirely acceptable, but that the opposite was true for larger items that one might need to borrow money for in order to purchase. Indeed, borrowing was seen by many participants as something 'other people' did, and that did not feature for them or many others who regularly shopped in pound stores. As Alan said,

if I wanted to be borrowing loads of money, I wouldn't be shopping in a pound store... it's because I prefer to only spend what I've got, that I like the pound store... you know where you are with it. If I've got a tenner, then that's what I can spend. I can buy ten things, and I have to choose between all the things I need, and I can't have everything.

This sense of a certain pride in maintaining the high street and the wider economy is interesting in light of Zygmunt Bauman's work on the 'flawed consumer'. He argues that while being poor used to derive its meaning from being unemployed, in today's society of consumers, it derives its meaning from being unable to purchase. This means that the poor, once a 'reserve army of labour', are re-cast as 'flawed consumers', which leaves them without a useful social function (Bauman, 2004: 1-3). Such flawed consumers are excluded from society and therefore feel that they are alone and that society cannot help them. Bauman (2004:116) argues that their place is 'out of sight', removed from the streets and other public places. The comments of respondents in this study, though, would suggest that the pound store, and its greater acceptance on the average high street (as opposed to only being accepted in very deprived areas), has provided the flawed consumer with somewhere acceptable to society that they can be seen, and indeed that they can actually exist as a consumer and have a part to play in the government's austerity rhetoric.

However, even those participants who were against austerity measures and the political rhetoric surrounding them more generally were not necessarily against personal responsibility or the attempt to 'scrimp and save' and 'find bargains'. Kay was fervently anti-austerity, but saw her pound store shopping as a personal choice, something that she would do regardless of 'whatever stupid and unfair policies the government decided to put in place'. For her, pound store shopping was about a personal choice to try to live inexpensively and 'simply' ignoring 'marketing messages'. Helen too, in her role as maven, felt she was 'beating the 
market at its own game and had no particular sympathy with government policies at all. Regardless, both Kay and Helen's shopping behaviour displayed consumptive thrift - purchasing wisely as opposed to not purchasing - which ironically was what the austerity message was concerned with. In fact, the rhetoric surrounding the initial austerity measures was explicitly moralistic in tone, causing commentators to describe David Cameron as neo-Victorian (see, for example, McWilliam, 2016). Household economia was placed at the forefront of political concerns, with levels of personal consumer debt flagged up and consumers warned in ways reminiscent of wartime that 'times would be tough', and so on. The pound store is, therefore, a useful tool for austerity policies and proponents, harnessing a reserve army of (flawed) consumers to continue consuming, regardless of whether they identify as being pro- or anti-austerity.

The fact that, regardless of their political views on austerity and the ways in which they themselves feel they are using pound store shopping, pound store consumer behaviour tends to conform to currently desirable economic trends and aims moves the debate on hedonic shopping away from traditional distinctions between the consumer as either dupe or free agent. Miller's view across his work has tended to depict the consumer as one of agency and freedom, expressing their self-identity through consumptive choices, in contrast to the consumer painted by thinkers such as Veblen (1994 [1899]), Lasch (1979) and Marcuse (1964), who is at the behest of powerful market sirens stirring up 'false needs'. However, if, regardless of the consumer's agency or lack of it, their behaviour can be hijacked as part of a political rhetoric that serves an ideological purpose in creating acceptance of cutbacks, it becomes crucial to find a different lens through which to understand the consumer. In this study, it appeared that despite having limited and in some cases severely limited financial choice, participants felt they had a degree of agency when choosing where to buy everyday products, and indeed often enjoyed that shopping, albeit in ways that were often defined as simply 'preferable' to other types of shopping. Yet their behaviour, regardless of their own agency, was a form of consumptive thrift that aided the needs of the austerity economy. The 'agency' of the consumer in this context, then, is better understood in relation to State interests for the economy and the extent to which they believe that it is their duty to be a consumer (even when they cannot afford it).

\section{Conclusion}

The attitudes and behaviours of those who participated in this study support Bardhi and Arnould's argument that thrift shopping is 'dialectic' in that it is motivated by both economic and hedonic desires. In this sense, it defies Daniel Miller's categorization of thrift shopping as purely economic. Regular pound store shoppers find pleasure through the functionality, simplicity and spontaneity of pound store shopping. In addition, many see their shopping in pound stores as 
playing a part in the economic health and even survival of high streets in less welloff areas. This is important as it is indicative of the extent to which consumers have internalized political rhetoric in which they are posited specifically as consumer-citizens, with 'consumer sovereignty' and 'consumer rights', and in return a duty to consume in certain ways. In this schema, under austerity, the subject's relationship to the State is being framed in highly moralistic terms when it comes to consumption. Well-informed consumptive thrift is the 'correct' way for citizens to respond to austerity and its impact in their everyday lives, and pound stores present some of the finest opportunities (apparently) for consumptive thrift, therefore aiding the embedding of austerity rhetoric and the acceptance of austerity policies.

Consumptive thrift in pound stores is certainly a dialectical process involving both economic and hedonic shopping. However, in occupying this dialectical position, it is also a crucial element in the publics' acceptance of both austerity rhetoric and the implementation of specific austerity policies. ${ }^{10}$ Consumer societies, by their very nature, require subjects who take their responsibility to consume seriously. The structure of the subject's position to the State and strategic relation to his or her own consumption as far as the State is concerned changes under austerity. This is not to suggest that consumers are brainwashed into consuming more, or indeed into a new relationship with the State, but rather that messages have become part of a culture that posits individuals as losing their worth if they are unable to consume - as being a weight that others have to carry - and this eventually starts to have an impact. This is not to underestimate the extent to which many regular bargain store consumers are simply trying to buy necessities at the lowest possible price rather than fulfilling a duty; rather, it is to recognize the extent to which the need to perpetuate the idea of the ability to buy (even as survival) has driven the growth of stores that enable buying for even the poorest.

As Miller (1998: 53) argues, supermarket marketing strategies make thrift appear to be available everywhere so that often shoppers need no price information to feel that they are practising thrift. Therefore, 'it is possible for shoppers to regard virtually the whole of the shopping expedition and the purchase of almost any specific item within that expedition, not as an act of spending at all, but as an act of saving' (Miller, 1998: 56). Such is the extent one might argue that capitalism has embedded itself in the idea and structures of thrift. To put it rather differently, capitalism, via the pound store, is successfully re-marketing thrift as consumptive thrift in order to support austerity. While consumers have their own motivations, pleasures and understandings of this, their behaviour (while hedonic to them) often supports the current austerity policies within the context of consumercapitalism more generally. It therefore becomes increasingly difficult for the consumer (even Bauman's flawed consumer) to behave in ways that genuinely resist austerity. 


\section{Notes}

1. In addition, however, Miller (1998) challenges the existing notions of thrift as a means to an end via short-term sacrifice, arguing that thrift can also be an autotelic activity.

2. While Bardhi and Arnould do not include such stores in their analysis of thrift shopping, their arguments are undoubtedly applicable to the data collected as part of this study.

3. See Hulme (2015).

4. Data from The Local Data Company show that, overall, the discount sector - including Poundland and its smaller rivals such as Poundworld and Poundstretcher - has grown by $48 \%$ over the past 5 years. This compares to the $34 \%$ expansion of the big four supermarket chains TESCO, Morrisons, Asda, and Sainsbury's - over the same period.

5. See https://www.theguardian.com/politics/2009/apr/26/davidcameron-conservative- economic-policy1

6. See BBC news at: http://news.bbc.co.uk/1/hi/8292680.stm

7. Dig for Victory was a Ministry of Agriculture campaign - a basic guide to growing vegetable crops in the garden or allotment. Make Do and Mend was a Ministry of Information pamphlet offering useful tips to housewives on how to be both frugal and stylish in times of strict clothes rationing to create (through the use of 'decorative patches', unpicking old jumpers to re-knit chic alternatives and turning men's clothes into women's) via the character of Mrs Sew-and-Sew.

8. Charles Alan Murray (1943-present) is an American libertarian political scientist, author, columnist and pundit. He became well known for his Losing Ground: American Social Policy 1950-1980, published in 1984, which discussed the American welfare system, and has written many controversial books since.

9. There is much written about the consumer-citizen, but worth mentioning in particular here is Frank Trentmann's body of work consumption, citizenship and nationalism, for example, his edited volume with Kate Soper, Citizenship and Consumption (Palgrave Macmillan, 2007).

10. In other work by the author, it is argued that the consumer is entirely capable of resisting capitalism's ability to use thrift for its own purposes (see A Brief History of Thrift, Hulme, 2019). However, pound stores are one of the strongest examples of capitalism's use of thrift as frugality.

\section{References}

- Bardhi F and Arnould E (2005) Thrift shopping: Combining utilitarian thrift and hedonic treat benefits. Journal of Consumer Behaviour 4(4): 223-233. 
- Bauman Z (2004) Work, Consumerism and the New Poor. Maidenhead: Open University Press.

- Bowlby R (2000) Carried Away: The Invention of Modern Shopping. London: Faber \& Faber.

- Bradshaw A (This Issue) Austerity and the fetish of the guilty consumer. Journal of Consumer Culture.

- Bramall R (2013) The Cultural Politics of Austerity: Past and Present in Austere Times. London: Palgrave Macmillan.

- Clarke J and Newman J (2012) The alchemy of austerity. Critical Social Policy 32(3): 299-P93.

- Falk P and Campbell C (1997) The Shopping Experience. London: Sage.

- Ginn F (2012) Dig for victory! New histories of wartime gardening in Britain. Journal of Historical Geography 38(3): 294-305.

- Hatherley O (2015) The Ministry of Nostalgia: Consuming Austerity. London: Verso Books.

- Hinton E and Redclift M (2009) Austerity and sufficiency: The changing politics of sustainable consumption. U.S. Politics and Development working paper series, Paper no. \#17. London: Department of Geography, King's College London. Available at: https://www. kcl.ac.uk/sspp/departments/geography/research/ResearchDomains/Contested-Develop ment/HIntonRedcliftWP17.pdf

- Hulme A (2015) On the Commodity Trail: The Journey of a Bargain Store Product from East to West. London: Bloomsbury.

- Hulme A (2016a) F**k the cupcake revolution! David Cameron, Samuel smiles, and the geographies of neo-Victorian thrift. Antipode. Available at: $\quad$ https://antipodefoundation.org/2016/06/07/fk-the-cupcakerevolution/

- Hulme A (2016b) The rise and rise of the pound store: Functionality and freedom under austerity. History of Retailing and Consumption 2: 165- 
170.

tandfonline.com/doi/abs/10.1080/2373518X.2016.1227922

- Hulme A (2019) A Brief History of Thrift. Manchester: Manchester University Press (MUP).

- Kynaston D (2010) Austerity was a hard sell in the 40s: Today it's harder still. The Guardian, 21 June. Available at: https://www.theguardian.com/commentisfree/2010/jun/21/austerityhard-sell-budget-2010 (accessed 4 September 2016).

- Lastovicka J, Bettencourt L, Hughner R, et al. (1999) Lifestyle of the tight and frugal: Theory and measurement. Journal of Consumer Behaviour 26: 85-97.

- McWilliam D (2016) London's dispossessed: Questioning the neoVictorian politics of neo-liberal austerity in Richard Warlow's Ripper street. Victoriographies 6(1): 42-61.

- Miller D (1998) A Theory of Shopping. Cambridge: Polity Press.

- Sherry F (1990) A sociocultural analysis of a Midwestern American flea market. Journal of Consumer Research 17(1): 13-30.

- Veblen T (1994 [1899]) Theory of the Leisure Class. New York: Dover. 